\title{
Sensitivity analysis of climate change impacts on dune erosion: case study for the Dutch Holland coast
}

\author{
R. C. de Winter ${ }^{1}$ (D) . B. G. Ruessink ${ }^{1}$
}

Received: 7 July 2016 / Accepted: 28 January 2017 / Published online: 23 February 2017

(C) The Author(s) 2017. This article is published with open access at Springerlink.com

\begin{abstract}
Climate change could have large implications for the management of dunefringed coasts. Sea level rise and changes in storm wave and surge characteristics could lead to enhanced dune erosion and hence a decrease in safety levels. Here, we use the processbased model XBeach to quantify the impact of sea level rise and changing hydrodynamic boundary conditions on the magnitude of future dune erosion at two locations along the Dutch coast. We find a linear relation between sea level rise and dune erosion volume, the exact linear relation being dependent on the local hydrodynamical boundary conditions. The process driving higher erosion appears to be sea level rise, allowing waves to attack the dune at a higher level. Additional simulations illustrate that a change in the offshore wave angle, potentially produced by changes in storm tracks, could influence the erosion volume with the same order of magnitude as sea level rise. Finally, simulations with different mitigation options (i.e., sand nourishments) illustrate the strong effect of the location of the added sand to the reduction in the dune erosion volume.
\end{abstract}

Keywords Dune erosion $\cdot$ XBeach $\cdot$ Sea level rise $\cdot$ Climate change $\cdot$ The Netherlands

\section{Introduction}

Global warming-induced climate change can have large implications for coastal safety. A region that is already prone to marine flooding and wave-induced erosion in the current climate is the North Sea area. The North Sea is a relatively shallow semi-enclosed sea (depths

RCdW and BGR acknowledge funding by the Utrecht University's focus area "Earth and Sustainability", sub-theme "Earth and Climate".

R. C. de Winter

r.c.dewinter@uu.nl

1 Department of Physical Geography, Faculty of Geosciences, Institute for Marine and Atmospheric Research, Utrecht University, P.O. Box 80.115, 3508 TC, Utrecht, The Netherlands 
in the south are $<50 \mathrm{~m}$ ), whose coasts experience high storm surge levels and waves during frequent extra-tropical storms (Spencer et al. 2015; De Winter et al. 2015). In particular, the Netherlands is considered to be an area sensitive to climate change (Parry et al. 2007; Beniston et al. 2007), because currently, $40 \%$ of the country is laying below mean sea level. The most densely populated area, also referred to as Holland, is protected from flooding by nearly uninterrupted sandy beaches and wind-blown dunes.

From a coastal perspective, the most obvious and presumably the best studied factor is sea level rise (SLR). Climate change could, however, also influence the offshore hydrodynamical boundary conditions (waves and storm surge levels) that impact coastal erosion. Together with SLR, this would endanger the stability and effectiveness of current hard defense and demand an up-scaling of soft-protection measures, such as mega-nourishments (Stive et al. 2013; de Schipper et al. 2016). It is, therefore, important to know to what extent coastal erosion could be affected by global warming-forced climate change and which hydrodynamical processes lead to these changes.

Traditionally, climate change effects on wave-dominated coasts have been assessed with the Bruun-rule (Bruun 1962). It predicts a retreat distance $R D$ of an equilibrium coastal profile equal to 50-200 times SLR, depending on the profile slope (e.g., Bruun 1962; Vellinga and Leatherman 1989; Zhang et al. 2004; FitzGerald et al. 2008, Nicholls and Cazenave 2010). In essence, the Bruun-rule uses SLR as the primary climate-related driver that affects coastal safety. Despite its frequent use, consensus is now arising that the Bruunrule is not suitable to analyze climate change effects on wave-dominated coasts (Cooper and Pilkey 2004; Zhang et al. 2004; Ranasinghe and Stive 2009; Ranasinghe et al. 2012). Among several other factors, these studies suggest that the impact of storms (i.e., dune erosion) on the long-term evolution of sandy beaches, and dunes cannot be neglected. Furthermore, the Bruun-rule does not allow for changes of the hydrodynamical boundary conditions.

Present-day safety standards in Dutch coastal policy were motivated by the 1953 storm surge disaster. A dune is considered to be safe if it will not breach during a storm with a of probability of 1:10,000. Based on various laboratory experiments (Van de Graaff 1977; Vellinga 1982; Van Gent et al. 2008), models were developed that assume a relation between storm impact and post-storm equilibrium dune profile. These models, such as DUROS (Vellinga 1983) and DUROS+ (Van Gent et al. 2008), are used to assess the dunes according the legal safety standards (Den Heijer et al. 2012).

For the Dutch coast, the dimensions of the 1:10,000-year hydrodynamical boundary conditions (waves and storm surge levels) are not expected to change under a changing climate. Based on the 17-member CMIP3 ESSENCE ensemble (Sterl et al. 2008), the 1:10,000-year storm surge (Sterl et al. 2009) and wave extremes (De Winter et al. 2012) are not projected to change along the Dutch coast. A generalized extreme value (GEV) analysis on annual maximum daily average wind speed data from 12 general circulation models (GCMs) on two climate scenarios (RCP 4.5 and RCP 8.5 ) did not reveal any coherent changes in annual maximum wind speeds, or in wind speeds with lower return frequencies above the North Sea basin (De Winter et al. 2013). There are, however, indications that the corresponding wave direction could shift (De Winter et al. 2012, 2013), because of a poleward shift of the storm track (CMIP3 (Bengtsson et al. 2006), CMIP5 (Harvey et al. 2012), and (Chang et al. 2012)). Sea level is projected to rise 0.15 to $0.8 \mathrm{~m}$ towards the end of this century (De Vries et al. 2014). From 2100 onwards, sea level will continue to rise, with Katsman et al. (2011) projecting changes up to $3.5 \mathrm{~m}$. SLR will increase the overall water level and therefore, also affect dune erosion by allowing waves to attack the dune at a higher level.

While changes in sea level and wave angle will be regional (Idier et al. 2013; Cazenave and Cozannet 2014; Slangen et al. 2014), coastal response will be local, depending on 
offshore bathymetric characteristics (e.g., Claudino-Sales et al. 2008), or the dune morphology themselves (e.g., Van Thiel De Vries et al. 2010; Den Heijer 2013; De Winter et al. 2015). Several impact assessments have been executed to evaluate the possible impact of climate change on local coastal hazards, such as the coast of Oregon, USA, where besides SLR, future occurrences of EL Niño are included (Baron et al. 2015) or the coasts of California, USA, where different types of coasts are present (e.g. cliffs, dunes) (Revell et al. 2011). Other studies focus specifically on impacts on coastal infrastructure (Brown et al. 2014).

For the Dutch coast, Li et al. (2013) concluded that dune erosion volumes at Noordwijk, the Netherlands, may increase by $8 \%$ for a SLR of $0.4 \mathrm{~m}$ and $17 \%$ for a SLR of $1.05 \mathrm{~m}$, using the DUNERULE model (Van Rijn 2009). In that study, impacts are assumed to be in the cross-shore direction. The assumption of cross-shore response only is however seriously criticized, and precludes its use in regions with large gradients in alongshore sand transports, such as near headlands or tidal inlets. Ruessink et al. (2012) have argued that to investigate this, a more general process-based approach is needed, for example by conducting simulation using the XBeach model (Roelvink et al. 2009). This is confirmed by Van Rijn (2009) and Den Heijer (2013) who indicate an increase in dune erosion with shore oblique waves. Another assessment of climate change impacts on the Dutch coasts concluded that changes in sea level will be dominant in the future, but that dunes can be maintained as flexible and primary defense for the Netherlands (Keijsers et al. 2015).

In this paper, we explore the impact of SLR and offshore wave angles $\theta$ in the range $0^{\circ}$ to $\sim 30^{\circ}$ on dune erosion. Furthermore, the near-shore processes are analyzed for the different erosion events. The analyses are preformed with the process-based model XBeach to project the effect of climate change on the 1:10,000-year dune erosion event along the Dutch coast at the local scale. In the simulations, we keep future wave heights and periods, as well as storm surges, identical to their present-day values, but increase sea level between 0.2 and $2.5 \mathrm{~m}$ and explore different $\theta$. We specifically run the simulations for two representative sites along the Dutch coast. As an initial assessment, we also analyze different mitigation options in reducing dune erosion volumes.

\section{Methods}

\subsection{Dune erosion model}

The process-based dune erosion model XBeach (version V19-Easter) is used to project bed level changes in response to a change in the hydrodynamical boundary conditions and various mitigation options. XBeach has been described extensively, for example by Roelvink et al. (2009) and McCall et al. (2010) and Splinter and Palmsten (2012). Therefore, we forgo this description here. The values of free model parameters are set to those derived from our earlier hydrodynamical and morphological calibration for the coast at Egmond aan Zee (De Winter et al. 2015).

\subsection{Hydrodynamical boundary conditions}

In the Netherlands, severe dune erosion events are caused by a combination of high water levels and high storm waves. The high water levels arise from superposition of a storm surge on a spring high tide. Several projections exist for SLR in the North Sea, depending on the climate scenario, the applied general circulation model (GCM), the time frame, and 
uncertainties in the driving processes behind SLR. We analyze the full bandwidth of projected SLR values in the North Sea basin resulting in SLR estimates of 0.2 to $2.5 \mathrm{~m}$ (Table 1). These low and high SLR estimates are based on KNMI'14 scenarios (De Vries et al. 2014) and the extreme climate change scenarios on Katsman et al. (2011). This range also covers the upper-limit SLR projections that includes the uncertainty in the driving processes such as ice sheet dynamics (Grinsted et al. 2015). In our simulations, the SLR is added to the present-day extreme design offshore surge level. We assume that the surge remains unaltered by the SLR-induced larger water depth, because, especially offshore, SLR is relatively small compared to total water depth.

Existing projections of extreme (1:10,000 year) conditions with the ESSENCE ensemble (Sterl et al. 2008), based on climate scenario SRES A1b, do not change with respect to present-day climate in front of the Dutch coast (see Sterl et al. (2009) for storm surge levels and De Winter et al. (2012) for wave height and period). It is, furthermore, shown that the change in offshore wave conditions is small when the water depth is increased by $1 \mathrm{~m}$; therefore, we assumed unaltered offshore wave and storm surge characteristics. Although the height and period of the extreme waves are not expected to change, the corresponding wave direction may shift to more westerly directions (Sterl et al. 2009, their Fig. 5) (De Winter et al. 2013, their Figs. 10 and 11). Although the Dutch coast has fetch limitations from other directions than north-west, we are interested in the sensitivity of dune erosion to changing $\theta$. The response to different $\theta$ could be of interest for coasts that could experience changing $\theta$. Moreover, the empirical dune erosion models presently used in coastal zone management assume shore-normal waves. We analyzed the effect of different $\theta$ for SLR $=0.4$ and $0.8 \mathrm{~m}$ by varying $\theta$ between $0^{\circ}$ (shore-normal) and $33.75^{\circ}$ (Table 2). This large range of $\theta$ is considered reasonable given the field measurement by Ruessink et al. (2001). SLR projections of 0.4 and $0.8 \mathrm{~m}$ were chosen to analyze the impact for different $\theta$ because they span the most likely SLR scenarios (low and high) for this century in the North Sea basin.

To investigate the possible effect of changes in hydrodynamical boundary conditions, we focus on two sites along the Dutch coast, Egmond aan Zee and Noordwijk aan Zee (hereafter Egmond and Noordwijk) (Fig. 1). Egmond is located $\sim 45 \mathrm{~km}$ north of Noordwijk and given the semi-enclosed geometry of the North Sea basin, the present-day 1:10,000-year surge level is lower at Egmond than that at Noordwijk, and the wave height and period are higher at Egmond. The 1:10,000-year hydrodynamical conditions used to assess the safety of the dunes are a surge level of $5.5(5.8) \mathrm{m}$, wave height $H_{\mathrm{m} 0}$ of $9.55(8.55) \mathrm{m}$, and wave period $T_{\mathrm{p}}$ of 16.1 (14.3) s for Egmond and Noordwijk, respectively (Ministerie van Verkeer en Waterstaat 2007). Also, at Egmond, the foredune is slightly higher (Fig. 2a, b).

\subsection{Model set-up}

Representative profiles are chosen for both locations (Egmond (De Winter et al. 2015) and Noordwijk (Jarkus section 8250 from 1997) and assumed to be alongshore uniform. The

Table 1 Sea level rise (m) for different climate change scenarios. For each individual combination, a bandwidth is given; details are given in the individual studies (De Vries et al. 2014; Katsman et al. 2011)

\begin{tabular}{llll}
\hline Type scenario outlook & 2050 & $2085(2100)$ & 2200 \\
\hline Low & 0.2 & 0.4 & - \\
High & 0.4 & 0.8 & 1.3 \\
Extreme & 0.4 & 1.3 & 2.5 \\
\hline
\end{tabular}


Table 2 Overview of the simulations executed for Egmond. For Noordwijk, only simulations with different SLR conditions conditions are executed and with $\theta=0^{\circ} . \theta$ is chosen as fractions of $45^{\circ}$ :

$45 / 8=5.625^{\circ}, 45 / 4=11.25^{\circ}$.

$45 / 2=22.5^{\circ}$ and

$45 / 1 \frac{1}{3}=33.75^{\circ}$

\begin{tabular}{llllll}
\hline $\operatorname{SLR}(\mathrm{m})$ & $\theta\left(^{\circ}\right)$ & $\theta\left(^{\circ}\right)$ & $\theta\left(^{\circ}\right)$ & $\theta\left(^{\circ}\right)$ & $\theta\left(^{\circ}\right)$ \\
\hline 0 & 0 & 5.625 & 11.25 & 22.5 & 33.75 \\
0.2 & 0 & & & & \\
0.4 & 0 & 5.625 & 11.25 & 22.5 & 33.75 \\
0.8 & 0 & 5.625 & 11.25 & 22.5 & 33.75 \\
1.30 & 0 & & & & \\
2.50 & 0 & & & & \\
\hline
\end{tabular}

profiles are extended in the offshore direction with 1000 to $30 \mathrm{~m}$ below mean sea level (MSL), to ensure that the short wind waves on the offshore boundary were non-breaking, and the generation of longer-period (20-200 s) infragravity waves, presumed as an important driver of beach and dune erosion (Russell 1993; Van Thiel De Vries et al. 2008), was still realistic. The latter also demands an area set-up of XBeach rather than the more standard profile mode, because of the effect of directional spread in the short waves on infragravitywave dynamics. In the cross-shore direction, the grid is $3000 \mathrm{~m}$ wide, with a grid resolution of $\Delta x=1 \mathrm{~m}$ at the dunes, coarsening up to $\Delta x=10 \mathrm{~m}$ at the offshore boundary. In the alongshore direction, the grid is $4000 \mathrm{~m}$ wide, with a grid resolution of $\Delta y=5 \mathrm{~m}$ in the center of the model domain, increasing to $\Delta y=15 \mathrm{~m}$ near the lateral boundaries. The median grain size is set to $200 \mu \mathrm{m}$ at both sites.

We set the hydrodynamics to spin up for $1 \mathrm{~h}$, before the simulations are executed an additional $5 \mathrm{~h}$ with morphological changes. The time step of the calculations is $1 \mathrm{~s}$. Vellinga

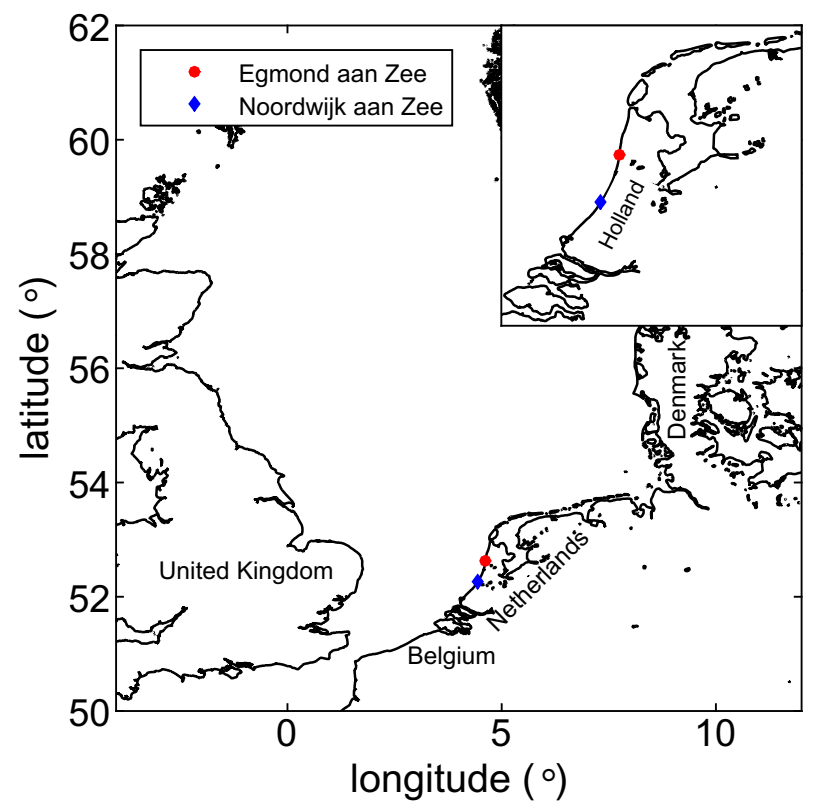

Fig. 1 The North Sea basin and a close-up of the Netherlands with the locations of Egmond (red circle) and Noordwijk (blue square). The distance between Egmond and Noordwijk is $\sim 45 \mathrm{~km}$ 

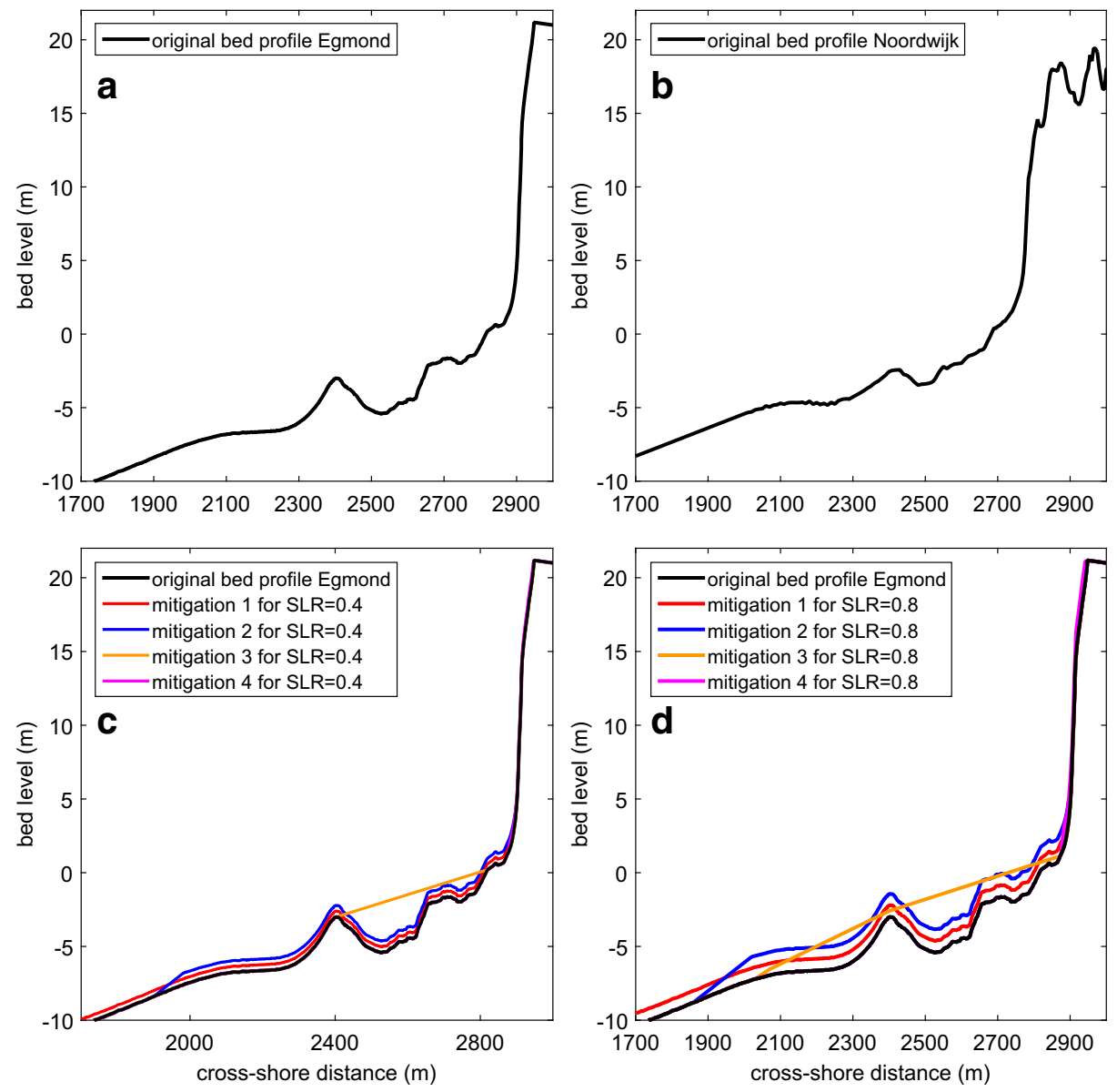

Fig. 2 a Initial bed profile Egmond; $\mathbf{b}$ initial bed profile Noordwijk; $\mathbf{c}$ initial bed profile Egmond and the four mitigation options for SLR $=0.4 \mathrm{~m}$; $\mathbf{d}$ initial bed profile Egmond and the four mitigation options for $\mathrm{SLR}=0.8 \mathrm{~m}$

(1986) showed that after $5 \mathrm{~h}$ with constant conditions, erosion volumes are similar to those under a storm, in which the effect of time-varying tide and surge levels were also taken into account.

Bed levels are written to an output file every half an hour after model spin up. The center of the domain $(y=1500-2500 \mathrm{~m})$ is used to analyze the morphological changes. In the middle of the domain at $y=2000 \mathrm{~m}$ between $x=2400$ and $2950 \mathrm{~m}$ hydrodynamical point, data are stored every second, with a cross-shore resolution of 10 to $20 \mathrm{~m}$. All elevation data shown are relative to Dutch Ordnance Datum (NAP), which is approximately current MSL. The effect of SLR and $\theta$ on dune erosion is analyzed using the erosion volume $V$, defined as the negative volume difference per unit of alongshore length between the pre- and 
post-storm profiles. Although the topography is alongshore uniform, some alongshore variation was always present in the post-storm topography. This presumably resulted from the short-crestedness of the incident storm waves. These alongshore differences in $V$ are used to calculate the standard deviation (std) of the erosion volume.

\subsection{Mitigation measures}

The cross-shore profiles in the simulation discussed in the previous subsection are presentday profiles. Current coastal policy in the Netherlands, however, prescribes that the amount of water in the coastal zone up to $20 \mathrm{~m}$ depth should remain the same. As a consequence, large-scale sand nourishments, such as the recently implemented Sand Engine (Stive et al. 2013; de Schipper et al. 2016), are foreseen. In this policy, no guidelines are provided as to where in the cross-shore profile sediment should be added to compensate for SLR.

We analyzed the effectiveness of the sediment volume that should be added for a SLR of 0.4 and $0.8 \mathrm{~m}$ for the Egmond profile, using several mitigation options. The amount of sand that should be added is determined by taking the cross-shore distance between +3 and $-15 \mathrm{~m}$ NAP which is $1894 \mathrm{~m}$ (below $-15 \mathrm{~m}$ NAP the grid was artificially extended, Section 2.3), resulting in 750 and $1500 \mathrm{~m}^{3} / \mathrm{m}$ for a SLR of 0.4 and $0.8 \mathrm{~m}$, respectively. In the first mitigation option we analyze, the sand is added over the total profile between -15 and +3 m NAP; as a result, the bed level increase is the same as SLR. In the second mitigation option, the sand is added between -8 and $+3 \mathrm{~m}$ NAP, elevating the bed level by 0.79 and $1.57 \mathrm{~m}$, respectively. In the third mitigation option, the sand is added between the inner and outer bar, or in case of a SLR of $0.8 \mathrm{~m}$ around the area of the inner and outer bar as otherwise the added volume of sand would not fit. The fourth mitigation option differs from the other three. Here, we reinforce the dune face, from the dune foot (+3 m NAP) to dune crest, with the difference in $V$ between the simulation with and without SLR (discussed in Section 3.1). With this mitigation option, we tested how effective it is to add sand to the dune face. All mitigation measures are depicted in Fig. 2c, d. The median grain size and the sorting of grain sizes are assumed to remain unaltered.

\section{Results}

\subsection{Sea level rise}

The projected $V$ for the present-day 1:10,000-year conditions without SLR and shorenormal waves are 335 and $230 \mathrm{~m}^{3} / \mathrm{m}$ for Egmond and Noordwijk, respectively (Fig. 3). These results are comparable to volumes estimated on 1:10,000-year laboratory experiments reported in Vellinga (1982) and Van Rijn (2009). This provides confidence that our process-based simulations are realistic. The lower $V$ at Noordwijk presumably results from the lower wave height and period. These numbers are in consonance with the observed $V$ during a number of storms in the last century (Fig. 3), with surge levels between 2 and $4 \mathrm{~m}$ above NAP and milder wave conditions compared to the 1:10,000-year storms. These historical storms show the importance of storm surge levels for dune erosion, as also indicated by Van de Graaff (1986). 


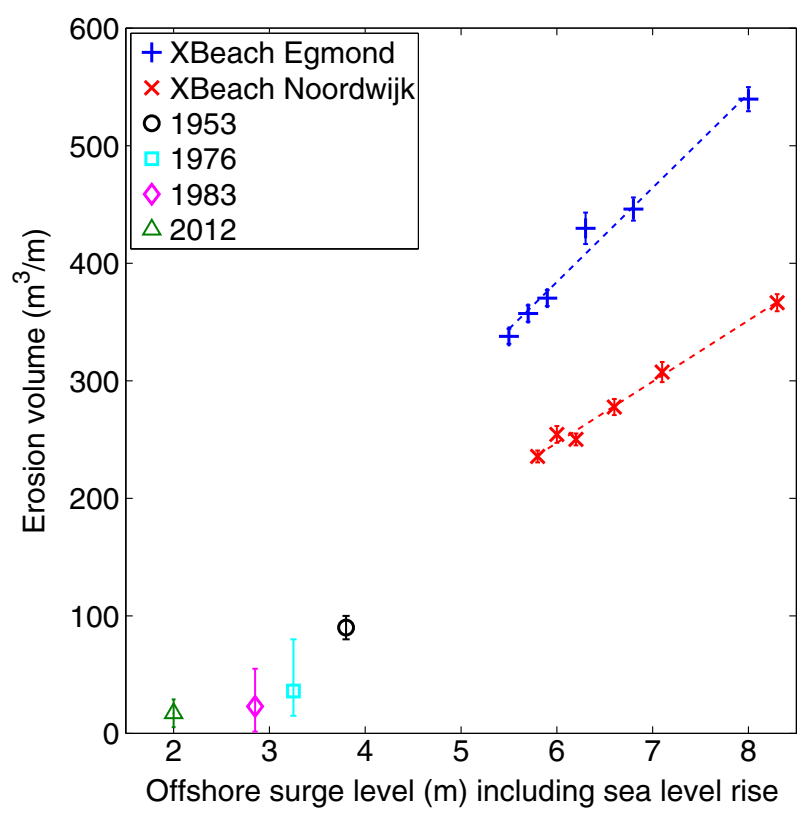

Fig. 3 Erosion volume $V$ as a function of offshore surge level including sea level rise. The values for surge levels above $5 \mathrm{~m}$ are XBeach projections for Egmond (blue) and Noordwijk (red). The vertical bar indicates the \pm 1 standard deviation. The lines through the model projections are the best-fit linear regression lines. The symbols at lower surge levels (and wave heights) are observations from the Dutch coast in the existing literature (1953, 1976, and 1983: De Vries et al. (2012); 2012: De Winter et al. (2015))

For both sides, there is a linear relation between SLR and $V\left(80(23.9 \%) \mathrm{m}^{3} / \mathrm{m}\right.$ per $\mathrm{m}$ SLR at Egmond and $52(22.6 \%) \mathrm{m}^{3} / \mathrm{m}$ at Noordwijk, Fig. 3). These numbers are slightly higher than the increase in erosion due to SLR suggested by Li et al. (2013) who concluded that erosion volumes will increase by $17 \%$ at Noordwijk with $1.05 \mathrm{~m}$ of SLR. In literature (Vellinga and Leatherman 1989; Zhang et al. 2004; FitzGerald et al. 2008; Nicholls and Cazenave 2010) coastal change with respect to SLR was linked primarily to $R D$, where $R D$ is defined as the horizontal retreat of the cross-section of the dune under an offshore surge level including SLR in the pre- and post-storm profile. In our simulation, $R D$ is larger for Noordwijk than for Egmond (e.g., $R D=15 \mathrm{~m}$ in Egmond and $25 \mathrm{~m}$ in Noordwijk for SLR of $1.3 \mathrm{~m}$ ). This is presumably related to the lower dune height at Noordwijk. At each location, the $R D$ increases with higher sea level. However, due to local dune-profile fluctuations, there is no linear relation between SLR and $R D$ in our simulations as suggested in the literature. We believe that erosion volume $V$ would be a better standard than $R D$.

The near-shore hydrodynamical conditions are likely to vary between the runs with different SLR, despite the identical offshore wave conditions. To examine what influences $V$, we evaluate the significant height of short-wave $H_{\mathrm{ss}}$, the significant infragravity-wave height $H_{\text {inf }}$, and the average water level $z_{s}$ for a $300 \mathrm{~m}$ transect perpendicular to the dune foot during the final $2 \mathrm{~h}$ of the simulations. In the simulations with a higher offshore water level, the $H_{\mathrm{ss}}$ is higher at a given cross-shore position, while $H_{\text {inf }}$ seems to be largely independent of the offshore storm surge levels (Figs. 4 and 5). The near-shore $H_{\text {inf }}$ of $\sim 1.5 \mathrm{~m}$ is consistent with the observations of Ruessink (2010) with offshore $H_{\mathrm{ss}}$ of $8 \mathrm{~m}$ and a $T_{\mathrm{p}}$ of 


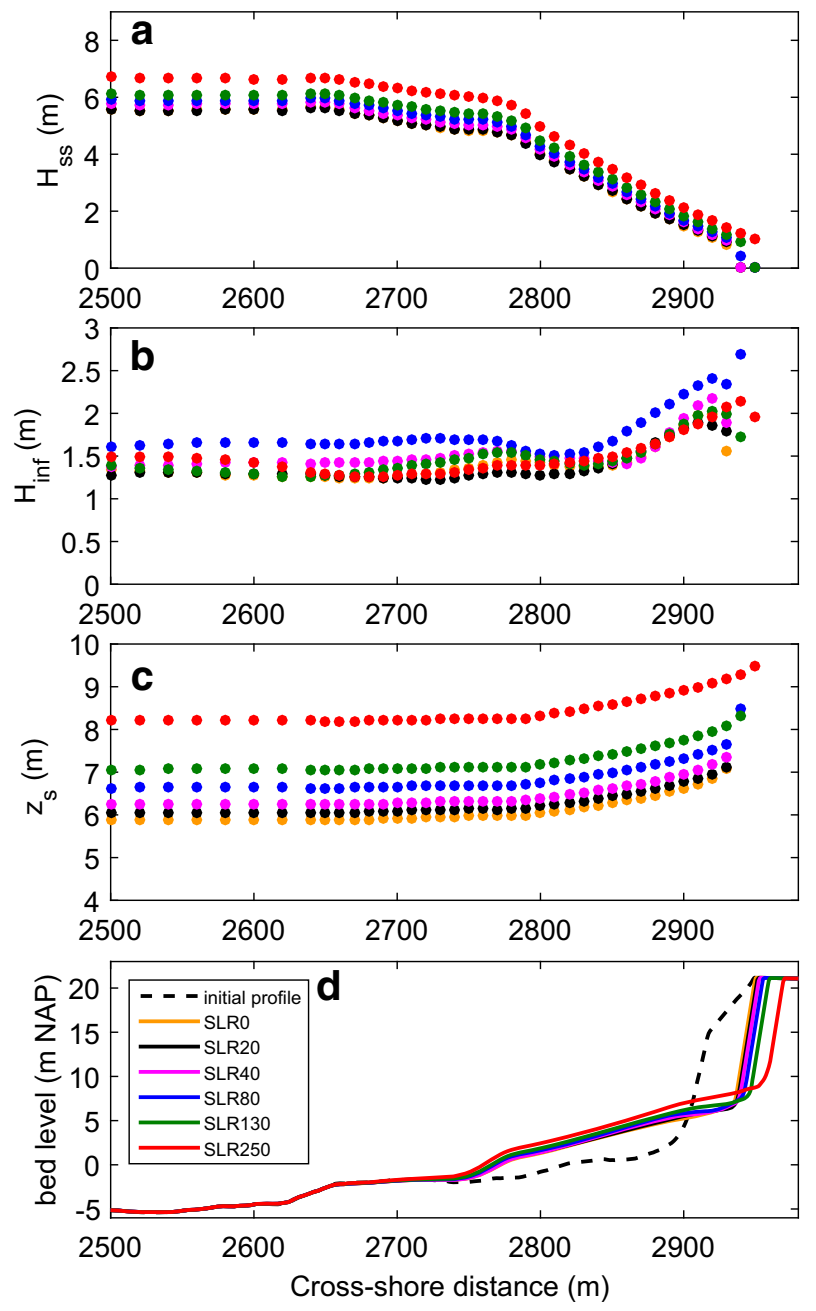

Fig. 4 Hydrodynamical conditions of the last $2 \mathrm{~h}$ versus cross-shore distance at Egmond: a significant height of short-wave $H_{\mathrm{ss}}(\mathrm{m})$; b significant infragravity wave height $H_{\mathrm{inf}}(\mathrm{m})$; $\mathbf{c}$ total water level $\mathrm{z}_{s}(\mathrm{~m})$; d initial and final profiles. Color coding for the various sea level rise (SLR) values is provided in the legend of panel $\mathbf{d}$

$\sim 15 \mathrm{~s}$, collected at the French Aquitanian coast. Obviously, a higher offshore storm surge level results in a higher $z_{s}$ in the near-shore zone. As a result of this larger water depth, short-wave energy is dissipated closer to the dunes. In combination with the higher level of impact, this results in larger $V$. Therefore, we characterize the increase of near-shore water level as the dominant driver behind the increasing $V$ under SLR conditions.

\subsection{Angle of wave incidence}

The effect of small deviations of $\theta$ from shore-normal (from $\theta=0^{\circ}$ to $\theta=5.625^{\circ}$ ) is limited and $V$ from the simulations with these $\theta$ are within each others bandwidth (Fig. 6). As soon 

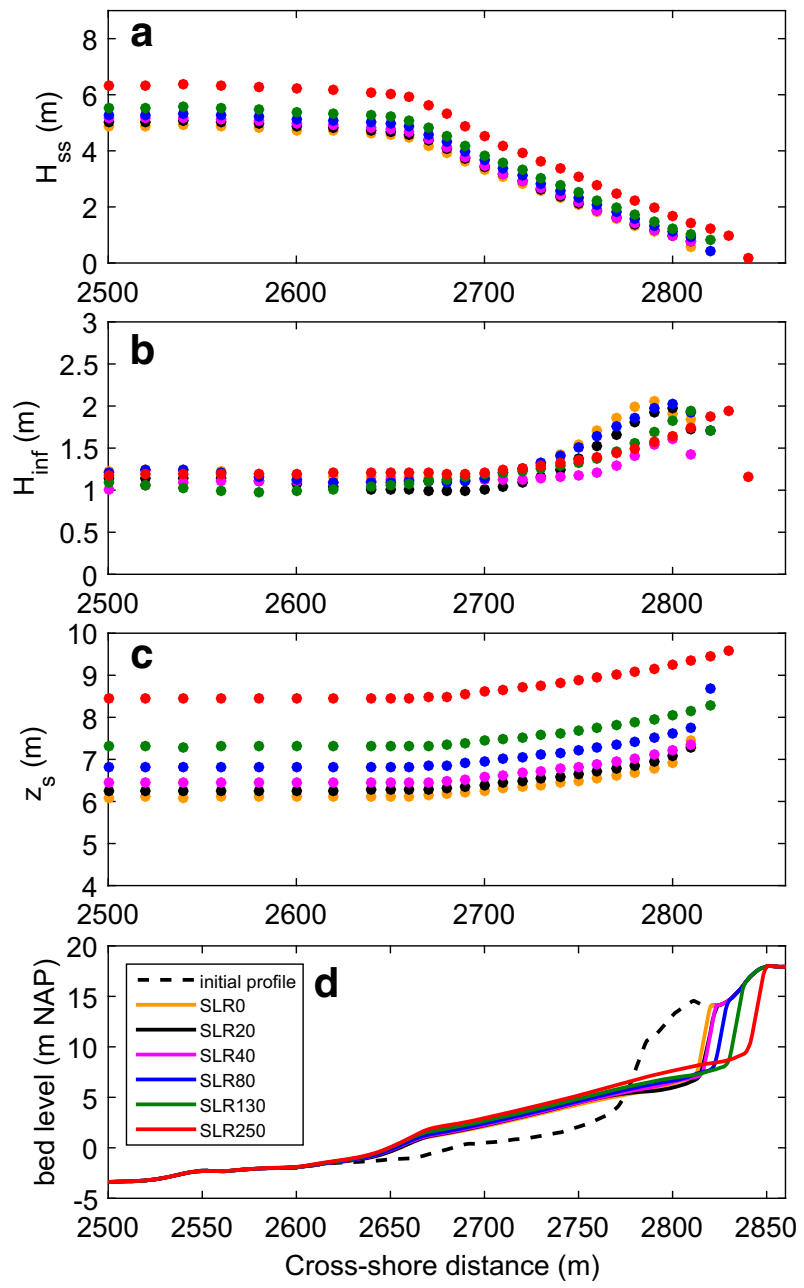

Fig. 5 As Fig. 4 now for Noordwijk

as $\theta$ increases to $11.25^{\circ}$ and larger, the increase of $V$ becomes more pronounced (Fig. 6). For the runs without SLR (surge level $5.5 \mathrm{~m}$ ), $V$ increases from 340 to $380 \mathrm{~m}^{3} / \mathrm{m}$ for $\theta=33.75^{\circ}$. The $40 \mathrm{~m}^{3} / \mathrm{m}$ change is equivalent to that of an SLR of about $0.4 \mathrm{~m} \mathrm{SLR}$ for shore-normal waves, and indicates that climate change-induced changes in $\theta$ may affect $V$ to a similar degree as SLR under a mild climate scenario. The change in $V$ due to $\theta$ is most prominent when $\theta$ deviates from shore-normal to $11.25^{\circ}$, for larger $\theta$, the increase in $V$ levels off. Simulations with a SLR of 0.4 and $0.8 \mathrm{~m}$ show a similar increase in $V$ when $\theta$ becomes larger than $11.25^{\circ}$.

The increase in $V$ with $\theta$ results from strong, wave-generated alongshore currents $v$ in front of the eroding dune (Fig. 7). Other hydrodynamical variables $\left(H_{\mathrm{ss}}, H_{\mathrm{inf}}, z_{s}\right.$, and the cross-shore velocity $u$ ) are approximately the same for different $\theta$. The large $v$-velocities enhance sand stirring (e.g., Thornton et al. 1996) leading to larger offshore $u$-induced 


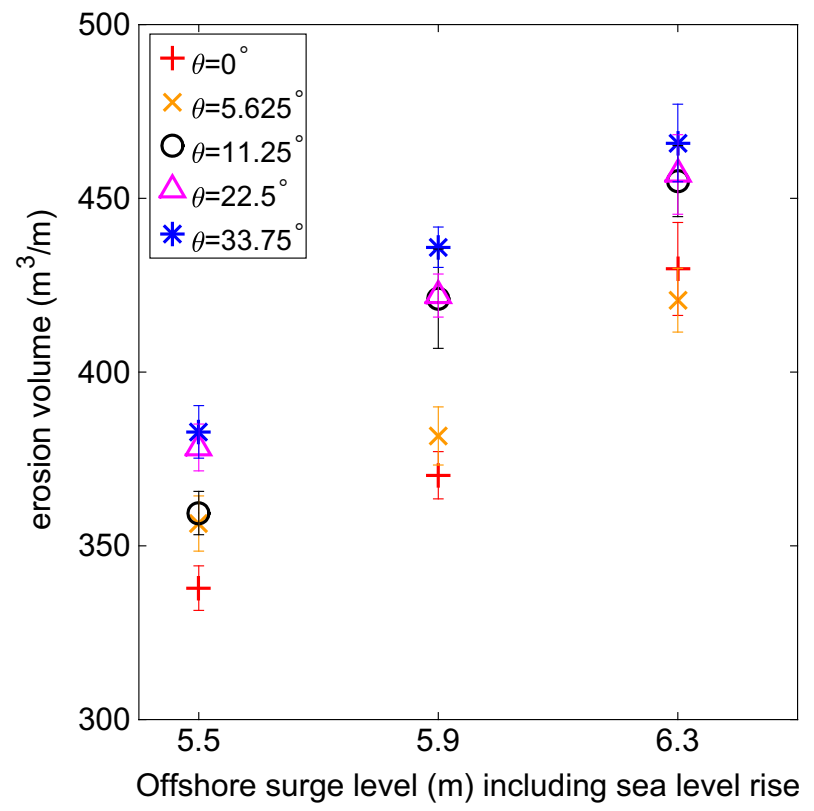

Fig. 6 Projected erosion volume $V$ versus offshore surge level including sea level rise (SLR) at Egmond for the various SLR $(0,0.4,0.8 \mathrm{~m})$ and wave-angle simulations. The vertical error bars represent \pm 1 standard deviation

transport, and thus larger $V$. Furthermore, with increased $v$, sand that is deposited in front of a dune after slumping is redistributed and cannot function as a buffer for subsequent wave impacts. Flume experiments (Van Thiel De Vries et al. 2008) and field observations (Carter and Stone 1989) show that dune erosion is a non-continuous process and accidental large parts of sand are eroded from the dunes. The eroded sand had to be removed from the dune foot, in order to make the dune front unstable again and to facilitate the next mass movement. This removal can be accelerated by alongshore currents. We are unaware of observations that show a $v$ of $\sim 2.5 \mathrm{~m} / \mathrm{s}$. In observations of Ruessink (2010), $v$ peaked at $\sim 1.5 \mathrm{~m} / \mathrm{s} ; v$, however, depends strongly on the cross-shore measurement location.

Even though extreme (1:10,000 year) waves in front of the Dutch coast are expected to come from the north-west (and hence shore oblique) due to fetch limitations for other directions, $\theta$ is assumed to be shore-normal in safety assessments. Our simulations indicate that a more realistic $\theta$ of $\sim 40^{\circ}$ would result in about $10 \%$ higher $V$ than shore-normal waves. Therefore, climate change-induced change in $\theta$ cannot be ignored in dune erosion studies. Furthermore, coasts exposed to extreme conditions from different directions should assess changes in the wave direction under climate change conditions, as this impact can be as large as, or in the same order of magnitude as SLR.

\subsection{Mitigation measures}

The effectiveness of the mitigation options are evaluated by how much they reduce $V$ and by how much $V$ is reduced relative to the sand volume added to the profile. The first mitigation option, where the bed level is elevated by the same magnitude as the sea level rises, results 

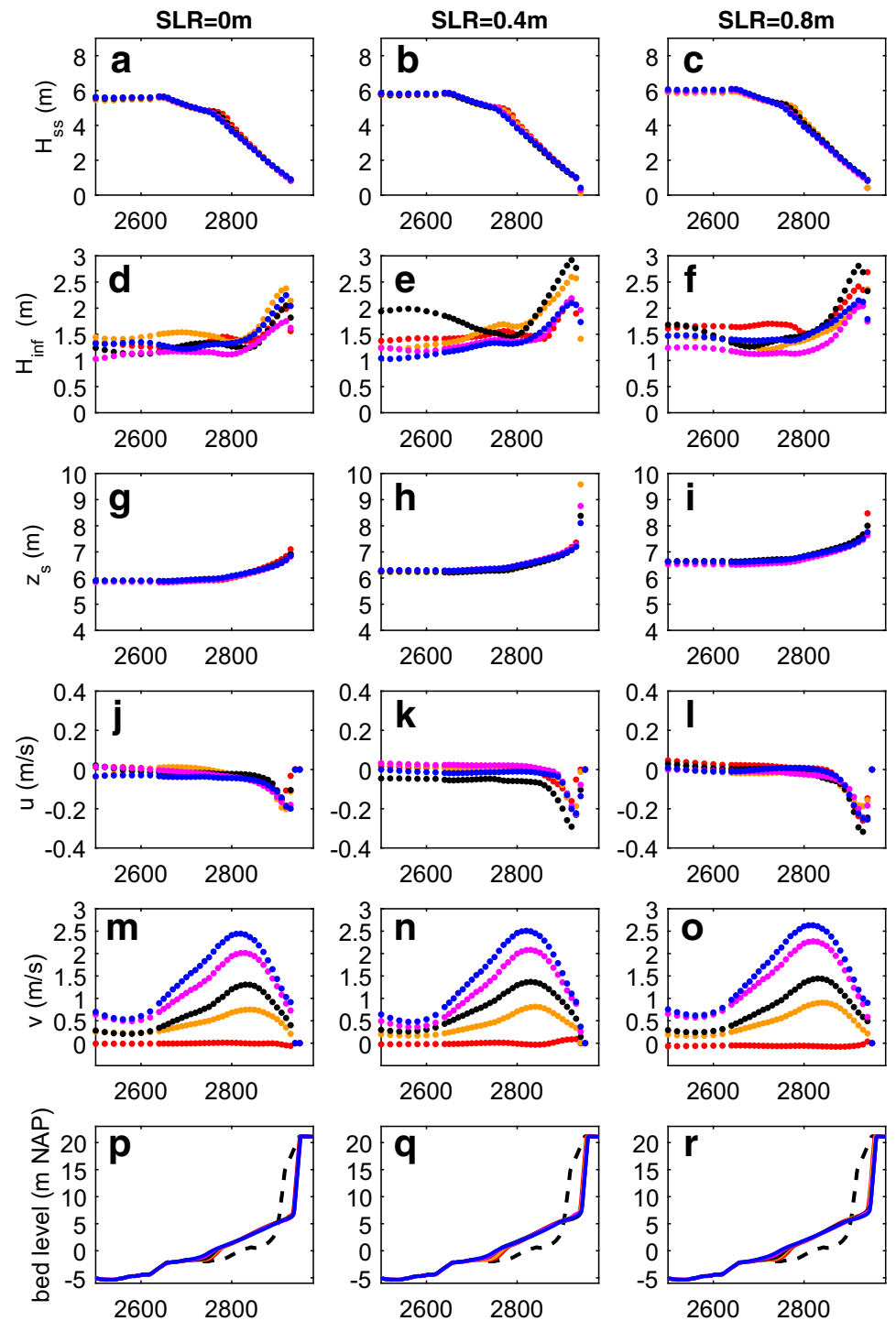

Cross-shore distance $(\mathrm{m})$ Cross-shore distance $(\mathrm{m})$ Cross-shore distance $(\mathrm{m})$

Fig. 7 Hydrodynamical conditions at Egmond for different wave angles $\theta$ and sea level rise (SLR), based on the final $2 \mathrm{~h}$ of the simulations. Left column SLR $=0 \mathrm{~m}$; middle column SLR $=0.4 \mathrm{~m}$; right column SLR $=0.8 \mathrm{~m}$. a-c Significant short-wave height $H_{\mathrm{ss}}(\mathrm{m}) ; \mathbf{d}-\mathbf{f}$ significant infragravity wave height $H_{\mathrm{inf}}(\mathrm{m})$; $\mathbf{g}-\mathbf{i}$ total water level $\mathrm{z}_{s}(\mathrm{~m}) ; \mathbf{j}-\mathbf{l}$ cross-shore velocity $u(\mathrm{~m} / \mathrm{s})$ positive directed land-wards; $\mathbf{m}-\mathbf{0}$ alongshore velocity $v(\mathrm{~m} / \mathrm{s}) ; \mathbf{p}-\mathbf{r}$ initial and final profiles. Colors are the same as $\theta$ coding in Fig. 6

in similar $V$ as in the simulation without SLR (Fig. 8a). Other mitigation options in which the same amount of sand is added, but at different locations in the profile (mitigation options 2 and 3), reduce $V$ to lower values compared to the situations without SLR. Figure $8 \mathrm{~b}$ depicts the effectiveness of the mitigation options. Although mitigation option 2 is the most effective option in reducing $V$, the ratio of reduced $V$ compared to volume of added sand 

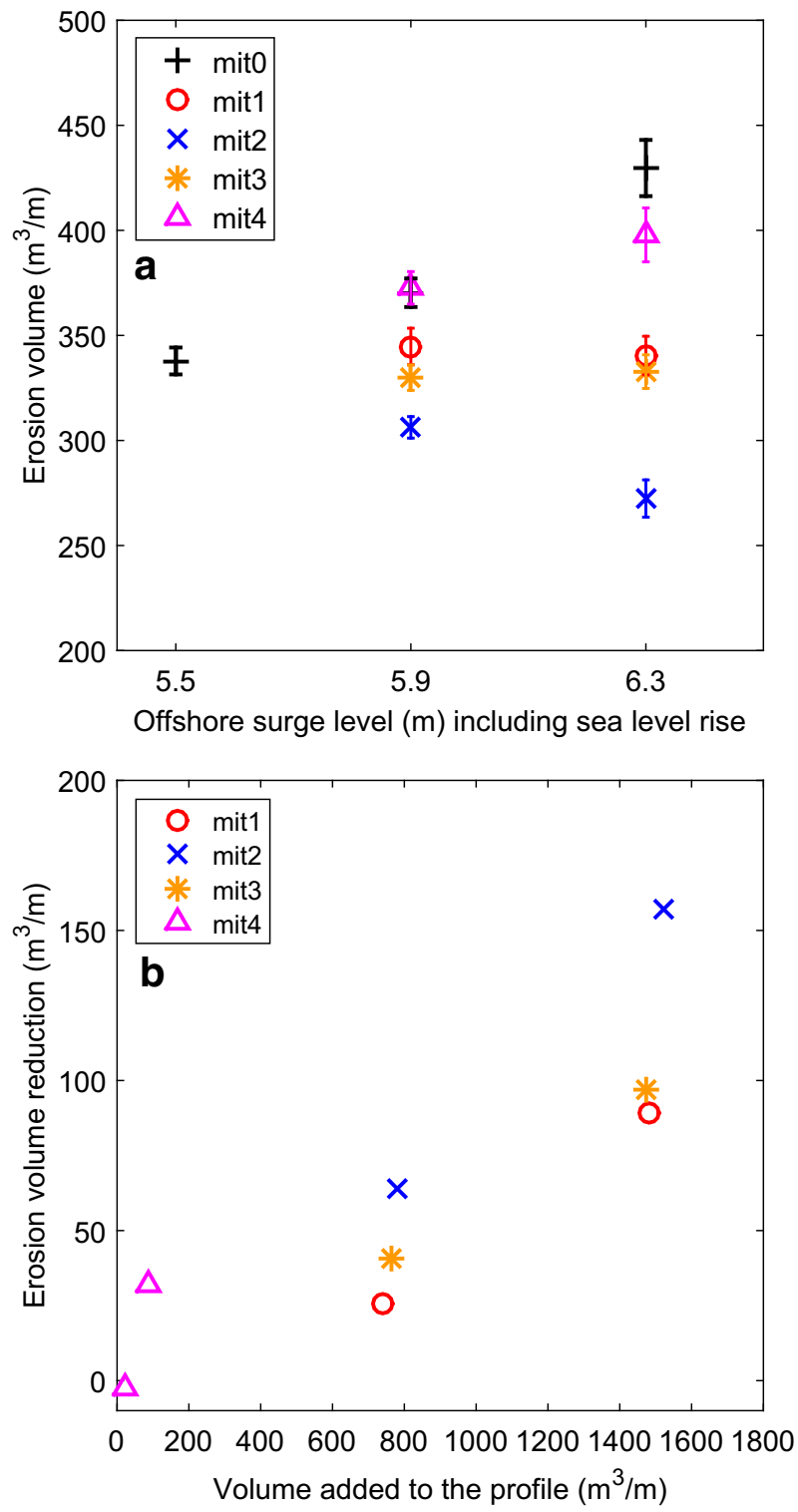

Fig. 8 a Projected erosion volume $V\left(\mathrm{~m}^{3} / \mathrm{m}\right)$ for the four mitigation options (mit) (Fig. 2c, d) versus offshore surge level $(\mathrm{m})$ including sea level rise; mit0 is the simulation with the original bed profile. $\mathbf{b}$ Reduction in $V\left(\mathrm{~m}^{3} / \mathrm{m}\right)$ versus total volume added to the profile $\left(\mathrm{m}^{3} / \mathrm{m}\right)$ for the four mitigation options

is relatively low $(\sim 0.1)$. In mitigation option 4 , where the increased $V$ due to SLR was directly added to the dune face, the ratio is $\sim 0.3$ for the simulation with a SLR of $0.8 \mathrm{~m}$. The same mitigation option for SLR of $0.4 \mathrm{~m}$ shows no $V$ reduction. Nonetheless, option 4 for SLR of $0.8 \mathrm{~m}$ does show that this option might also be effective to combat SLR-related dune erosion. 


\section{Discussion}

In our simulations, it is assumed that after $5 \mathrm{~h}$, dune erosion volume is compatible with a real storm in which the offshore water level fluctuates with the tide and the surge (Vellinga 1982; Ruessink et al. 2012). All our simulations were therefore carried out with $5 \mathrm{~h}$ of timeinvariant conditions. Reconsidering the original Vellinga-data, this $5 \mathrm{~h}$ duration is certainly open for discussion. Also under an increased sea level, the exposure time of the dunes to the waves may be larger. Furthermore, there is the possibility of sequential severe storms, without any intermediate coastal recovery. We briefly explored the sensitivity of $V$ to simulation duration by a $10 \mathrm{~h}$ simulation with the Egmond profile and SLR of $0 \mathrm{~m}$. The longer duration can be interpreted as a storm that lasts longer, or as two sequential storms, since the conditions are assumed to be constant (Vellinga 1983, their Fig. 14). Longer exposure of the dunes to extreme conditions indeed results in larger $V$. In the second half of the simulation (hours 6 to 10), $V$ does, however, not increase as rapidly as in the first $5 \mathrm{~h}$. The imposed $10 \mathrm{~h}$ storm results in $V$ of $450 \mathrm{~m}^{3} / \mathrm{m}$ compared to $340 \mathrm{~m}^{3} / \mathrm{m}$ for a $5 \mathrm{~h}$ storm, suggesting that changes in storm duration will affect $V$ substantially compared to the changes in $V$ induced by SLR or $\theta$. However, two storms in close succession do not simply double $V$.

In our analysis, we applied an alongshore uniform topography. In reality, dune topography can vary alongshore, resulting in alongshore variations in $V$ (De Winter et al. 2015). The dune erosion events we analyze here are much more extreme than the January 2012 storm analyzed in De Winter et al. (2015) (Fig. 3b). We repeated the present-day 1:10,000 condition on De Winter et al. (2015)'s alongshore variable topography and found that the ratio of the alongshore averaged $V$ compared to the standard deviation of $V$ amounted to $\sim 0.07$. This is higher than for the uniform topography $(\sim 0.02)$, but substantially less than the 0.68 obtained for the 2012 storm. The use of an alongshore uniform profile is therefore justified in this study.

The current Dutch policy towards SLR is to add the same volume of sand to the profile as the water volume increases as a result of SLR. Based on our simulations, this can be considered as a conservative approach, and a focus on dune strengthening in case of large SLR may be more effective. Furthermore, in the current policy, the location in the profile where sediment is added is not taken into account, while in our simulations, this influences $V$ strongly. The same safety standard as present day could be reached by using less sediment if the sand is used to increase the volume of the dunes. In this study, we performed a sensitivity analyses on the location of mitigation measures. In practice, however, this is also related to aspects outside the scope of this research, such as the costs of different types of nourishments, ecological considerations, the sediment sorting of the nourishment, and the behavior of a nourishment under influence of waves and aeolian processes.

Dune erosion events alternate with prolonged periods of dune accretion through aeolian processes. Climate change may affect these processes too. Changes in wind patterns and beach width can influence yearly aeolian supply to the foredunes. Enhanced dune erosion could lead to more blow-outs and, as a corridor for aeolian transport, stimulate the vertical growth of the more landward dunes. Enhanced erosion may, accordingly, not necessarily be bad for the beach dune system as a whole. SLR may impact the hydrology in the dunes and, together with changes in temperature and rainfall, alter vegetation patterns. Vegetation patterns influence the size of the avalanches during erosion events (Carter and Stone 1989). Future work should therefore also focus on climate change effects on coastal recovery and eco-physical feedback. 


\section{Conclusions}

Using the process-based XBeach model, we find a linear trend between the erosion volume $V$ and SLR, amounting to $80 \mathrm{~m}^{3} / \mathrm{m}$ per $\mathrm{m} \mathrm{SLR}$ at Egmond and $52 \mathrm{~m}^{3} / \mathrm{m}$ per $\mathrm{m}$ SLR at Noordwijk. This increase in erosion volume is primarily due to the larger water level in front of the dune and not due to to changes in the significant short-wave or infragravity wave height in the near-shore zone. Additional simulations indicate that the offshore angle of wave incidence $\theta$ also affects $V$. A $\sim 30^{\circ}$ shift from shore-normal could influence $V$ to the same extent as $0.4 \mathrm{~m}$ SLR. This increase in $V$ is related to strong alongshore currents, generated as a result of the obliquity of the waves, that enhance stirring and hence offshore transport and thus $V$. Simulations, in which we added sand to the profile with an amount equal to the water volume increase due to SLR, illustrate that the location in the profile where this sand is added influences the reduction in $V$ considerably. The ratio of the reduction in $V$ to the total added volume remains low $(<0.3)$ for all mitigation options. Possibly, mitigation measures that directly increase the volume of sand in the dunes may be more efficient from a morphological perspective.

Open Access This article is distributed under the terms of the Creative Commons Attribution 4.0 International License (http://creativecommons.org/licenses/by/4.0/), which permits unrestricted use, distribution, and reproduction in any medium, provided you give appropriate credit to the original author(s) and the source, provide a link to the Creative Commons license, and indicate if changes were made.

\section{References}

Baron HM, Ruggiero P, Wood NJ, Harris EL, Allan J, Komar PD, Corcoran P (2015) Incorporating climate change and morphological uncertainty into coastal change hazard assessments. Nat Hazards 75(3):20812102. doi:10.1007/s11069-014-1417-8

Bengtsson L, Hodges KI, Roeckner E (2006) Storm tracks and climate change. J Clim 19(15):3518-3543. doi:10.1175/JCLI3815.1

Beniston M, Stephenson DB, Christensen OB, Ferro CAT, Frei C, Goyette S, Halsnaes K, Holt T, Jylhä K, Koffi B, Palutikof J, Schöll R, Semmler T, Woth K (2007) Future extreme events in European climate: an exploration of regional climate model projections. Clim Chang 81:71-95

Brown S, Hanson S, Nicholls RJ (2014) Implications of sea-level rise and extreme events around Europe: A review of coastal energy infrastructure. Clim Chang 122(1):81-95. doi:10.1007/s10584-013-0996-9

Bruun P (1962) Sea-level rise as a cause of shore erosion. Journal of the Waterways and Harbors Division 88:117-130

Carter RWG, Stone GW (1989) Mechanisms associated with the erosion of sand dune cliffs, Magilligan, Northern Ireland

Cazenave A, Cozannet GL (2014) Sea level rise and its coastal impacts. Earth's Future 2:15-34. doi:10.1002/ 2013EF000188

Chang EKM, Guo Y, Xia X (2012) Cmip5 multimodel ensemble projection of storm track change under global warming. J Geophys Res 117:D23118. doi:10.1029/2012JD018578

Claudino-Sales V, Wang P, Horwitz MH (2008) Factors controlling the survival of coastal dunes during multiple hurricane impacts in 2004 and 2005: Santa Rosa barrier island, Florida. Geomorphology 95:295-315. doi:10.1016/j.geomorph.2007.06.004

Cooper JAG, Pilkey OH (2004) Sea-level rise and shoreline retreat: Time to abandon the Bruun rule. Glob Planet Chang 43:157-171

De Vries H, Katsman C, Hazeleger W, Drijfhout S (2014) Scenarios for sea-level change. Technical Report; Royal Netherlands Meteological Institute (KNMI)

De Vries S, Southgate HN, Kanning W, Ranasinghe R (2012) Dune behavior and aeolian transport on decadal timescales. Coast Eng 67:41-53. doi:10.1016/j.coastaleng.2012.04.002 
De Winter RC, Gongriep F, Ruessink BG (2015) Observations and modeling of alongshore variability in dune erosion at Egmond aan Zee, the Netherlands. Coast Eng 99:167-175. doi:10.1016/j.coastaleng. 2015.02.005

De Winter RC, Sterl A, Ruessink BG (2013) Wind extremes in the North Sea Basin under climate change: An ensemble study of 12 CMIP5 GCMs. Journal of Geophysical Research: Atmospheres 118:1601-1612. doi:10.1002/jgrd.50147

De Winter RC, Sterl A, de Vries JW, Weber SL, Ruessink BG (2012) The effect of climate change on extreme waves in front of the Dutch coast. Ocean Dyn 62:1139-1152. doi:10.1007/s10236-012-0551-7

Den Heijer C (2013) The role of bathymetry, wave obliquity and coastal curvature in dune erosion prediction. Ph.D. thesis; Deltares, Delft University of Technology

Den Heijer C, Baart F, van Koningsveld M (2012) Assessment of dune failure along the Dutch coast using a fully probabilistic approach. Geomorphology 143-144:95-103. doi:10.1016/j.geomorph.2011.09.010

FitzGerald DM, Fenster MS, Argow BA, Buynevich IV (2008) Coastal impacts due to sea-level rise. Ann Rev Earth Planet Sci 36:601-647. doi:10.1146/annurev.earth.35.031306.140139

Van de Graaff J (1977) Dune erosion during a storm. Coast Eng 1:99-134

Van de Graaff J (1986) Probabilistic design of dunes; an example from the netherlands. Coast Eng 9:479-500

Grinsted A, Jevrejeva S, Riva REM, Dahl-Jensen D (2015) Sea level rise projections for northern Europe under rcp8.5. Climate Research 64:15-23. doi:10.3354/cr01309

Harvey BJ, Shaffrey LC, Woollings TJ, Zappa G, Hodges KI (2012) How large are projected 21st century storm track changes. Geophys Res Lett 39(17):L18707. doi:10.1029/2012GL052873

Idier D, Castelle B, Poumadère M, Balouin Y, Bertoldo RB, Bouchette F, Boulahya F, Brivois O, Calvete D, Capo S, Certain R, Charles E, Chateauminois E, Delvallée E, Falqués A, Fattal P, Garcin M, Garnier R, Héquette A, Larroudé P, Lecacheux S, Le Cozannet G, Maanan M, Mallet C, Maspataud A, Oliveros C, Paillart M, Parisot JP, Pedreros R, Robin N, Robin M, Romieu E, Ruz MH, Thiébot J, Vinchon C (2013) Vulnerability of sandy coasts to climate variability. Clim Res 57:19-44

Katsman CA, Sterl A, Beersma JJ, Van den Brink HW, Church JA, Hazeleger W, Kopp RE, Kroon D, Kwadijk J, Lammersen R, Lowe J, Oppenheimer M, Plag HP, Ridley J, Von Storch H, Vaughan DG, Vellinga P, Vermeersen LLA, Van de Wal RSW, Weisse R (2011) Exploring high-end scenarios for local sea level rise to develop flood protection strategies for a low-lying delta-the netherlands as an example. Clim Chang 109:617-645

Keijsers JGS, Giardino A, Poortinga A, Mulder JPM, Riksen MJPM, Santinelli G (2015) Adaptation strategies to maintain dunes as flexible coastal flood defense in the Netherlands. Mitig Adapt Strateg Glob Chang 20(6):913-928. doi:10.1007/s11027-014-9579-y

Li F, Van Gelder PHAJM, Callaghan DP, Jongejan RB, Den Heijer C, Ranasinghe R (2013) Probabilistic modeling of wave climate and predicting dune erosion. J Coast Res 65:760-765. doi:10.2112/SI65-129

McCall R, Van Thiel de Vries JSM, Plant NG, Van Dongeren AR, Roelvink JA, Thompson DM, Reniers AJHM (2010) Two-dimensional time dependent hurricane overwash and erosion modeling at Santa Rosa Island. Coast Eng 57:668-683. doi:10.1016/j.coastaleng.2010.02.006

Ministerie van Verkeer en Waterstaat (2007) Hydraulische Randvoorwaarden 2006 voor het toetsen van primaire waterkeringen (in Dutch). Technical Report; Ministerie van Verkeer en Waterstaat

Nicholls R, Cazenave A (2010) Sea-level rise and its impact on coastal zones. Science 328:1517-1520. doi:10.1126/science. 1185782

Parry ML, Canziani OF, Palutikof JP, van der Linden PJ, Hanson CE (2007) Contribution of Working Group II to the Fourth Assessment Report of the Intergovernmental Panel on Climate Change. Cambridge University Press, Cambridge and New York

Ranasinghe R, Callaghan D, Stive MJF (2012) Estimating coastal recession due to sea level rise: beyond the Bruun rule. Clim Chang 110:561-574

Ranasinghe R, Stive MJF (2009) Rising seas and retreating coastlines. Clim chang 97:465-468

Revell DL, Battalio R, Spear B, Ruggiero P, Vandever J (2011) A methodology for predicting future coastal hazards due to sea-level rise on the California Coast. Clim Chang 109(1):251-276. doi:10.1007/s10584011-0315-2

Roelvink D, Reniers A, van Dongeren A, van Thiel de Vries J, McCall R, Lescinski J (2009) Modelling storm impacts on beaches, dunes and barrier islands. Coast eng 56:1133-1152. doi:10.1016/j.coastaleng. 2009.08.006

Ruessink B (2010) Observations of turbulence within a natural surf zone. J Phys Oceanogr 40:2696-2712. doi:10.1175/2010JPO4466.1

Ruessink BG, Boers M, Van Geer PFC, De Bakker ATM, Pieterse A, Grasso F, De Winter RC (2012) Dune erosion along the Dutch Wadden coast: coastal management, laboratory experiments and field studies. Geologie en Mijnbouw/Netherlands Journal of Geosciences 91:357-372 
Ruessink BG, Miles JR, Feddersen F, Guza RT, Elgar S (2001) Modeling the alongshore current on barred beaches. J Geophys Res C Oceans C10:22451-22463

Russell P (1993) Mechanisms for beach erosion during storm. Cont Shelf Res 13:1243-1265

de Schipper MA, de Vries S, Ruessink G, de Zeeuw RC, Rutten J, van Gelder-Maas C, Stive MJF (2016) Initial spreading of a mega feeder nourishment: observations of the Sand Engine pilot project. Coast Eng 111:23-38. doi:10.1016/j.coastaleng.2015.10.011

Slangen ABA, Carson M, Katsman CA, Van de Wal RSW, Köhl, Vermeersen A, A. LL, Stammer D (2014) Projecting twenty-first century regional sea-level changes. Clim Chang 124:317-332

Spencer T, Brooks SM, Evans BR, Tempest JA, Möller I (2015) Southern North Sea storm surge event of 5 December 2013: water levels, waves and coastal impacts. Earth Sci Rev 146:120-145

Splinter KD, Palmsten ML (2012) Modeling dune response to an east coast low. Mar Geol 329-331:46-57. doi:10.1016/j.margeo.2012.09.005

Sterl A, Van den Brink H, De Vries H, Haarsma R, van Meijgaard R (2009) An ensemble study of extreme storm surge related water levels in the North Sea in a changing climate. Ocean Sci 5:369

Sterl A, Severijns C, Dijkstra H, Hazeleger W, Van Oldenborgh GJ, Van den Broeke M, Burgers G, Van den Hurk B, Van Leeuwen PJ, Van Velthoven P (2008) When can we expect extremely high surface temperatures? Geophys Res Lett 35:L14703. doi:10.1029/2008GL034071

Stive MJF, De Schipper MA, Luijendijk AP, Aarninkhof SGJ, Van Gelder-Maas C, Van Thiel De Vries JSM, De Vries S, Henriquez M, Marx S, Ranasinghe R (2013) A new alternative to saving our beaches from sea-level rise: the sand engine. J Coast Res 29:1001-1008. doi:10.2112/JCOASTRES-D-13-00070.1

Thornton EB, Humiston RT, Birkemeier W (1996) Bar/trough generation on a natural beach. J Geophys Res C Oceans 101:12097-12110

Van Gent MRA, van Thiel de Vries JSM, Coeveld EM, de Vroeg JH, van de Graaff J (2008) Large-scale dune erosion tests to study the influence of wave periods. Coast Eng 55:1041-1051. doi:10.1016/j.coastaleng. 2008.04.003

Van Rijn LC (2009) Prediction of dune erosion due to storms. Coast Eng 56:441-457. doi:10.1016/j.coasta leng.2008.10.006

Van Thiel De Vries J, Dongeren AV, McCall R, Reniers A (2010) The effect of the longshore dimension on dune erosion. In: Proceedings of the Coastal Engineering Conference

Van Thiel De Vries JSM, van Gent1 MRA, Walstra DJR, Reniers AJHM (2008) Analysis of dune erosion processes in large-scale flume experiments. Coast Eng 55:1028-1040. doi:10.1016/j.coastaleng. 2008.04.004

Vellinga P (1982) Beach and dune erosion during storm surges. Coast Eng 6:361-387

Vellinga P (1983) Proceedings Coastal Structures Predictive computational model for beach and dune erosion during storm surges. ASCE, New York, pp 806-819

Vellinga P (1986) Beach and dune erosion during storm surges. Ph.D. thesis; Delft University

Vellinga P, Leatherman SP (1989) Sea level rise, consequences and policies. Clim chang 15:175-189. doi:10.1007/BF00138851

Zhang K, Douglas BC, Leatherman SP (2004) Global warming and coastal erosion. Clim Chang 64:41-58. doi:10.1023/B:CLIM.0000024690.32682.480 